\title{
An Empirical Investigation on the Impact of Corporate Social Responsibility on Brand Equity within Perceived Service Quality Framework
}

\author{
Hassan, Ghorbani \\ Department of Management and Accounting, Islamic Azad University \\ Mobarakeh Branch, Isfahan, Iran \\ E-mail: ghorbani2007ha@yahoo.com
}

Seyedeh Masoomeh, Abdollahi

Department of management, University of Isfahan, Isfahan, Iran

E-mail: masumeh_abdolahi@yahoo.com

Mehdi Chini

Department of Management and Accounting, Islamic Azad University

Mobarakeh Branch, Isfahan, Iran

E-mail:nemachinco@yahoo.com

Doi:10.5901/mjss.2013.v4n6p119

\section{Abstract}

Corporate social responsibility is viewed both as an organizational function as well as a means to establishing stakeholder relations and reputations. This study aims to investigate the impact of social activities of an organization on its brand equity regarding perceived service quality framework. The statistical population consists of Iran's household appliance companies. Random sampling method has been applied to select the appropriate sample. The examinations were done through 312 available questionnaires. In order to test the conceptual model, structural equations' model (SEM) has been used. Results based on SEM outputs demonstrate acceptance and confirmation of all studied factors. These findings indicate that Corporate Social Responsibility can influence brand equity. Perceived service quality also found to affect advertising effectiveness. Finally the impact of advertising effectiveness on brand equity was confirmed statically.

Keywords: CSR, Perceived Service Quality, brand equity, advertising effectiveness.

\section{Introduction}

Today's competitive service market environments make corporate social responsibility (CSR) a high profile notion with strategic importance to many companies (Luo and Bhattacharya, 2006). Corporate social responsibility (CSR) initiatives have experienced an unprecedented growth in recent years (Barone et al., 2000). Companies have to involve in different types of social responsibility activities, such as acts of responsibility towards the environment, treating employees fairly or contributions to art and cultural programs in the community (Barone et al., 2000). On the other hand, discussing the relationship of CSR initiatives and positive outcomes has also increased in the last few years (Argenti et al., 2005). Bhattacharya and Sen (2004) establish some of internal outcomes of CSR activities such as awareness, attachment and attitudes as well as external outcomes like purchase, word of mouth and loyalty. Therefore, it can be claimed that CSR has become an essential element of corporate marketing strategies, specially empowering corporate branding (Poolthong and Mandhachitara, 2009; Pirch et al., 2007). Moreover, besides strengthening core corporate capabilities, CSR is often proposed as a means to build positive attitudes towards companies among their consumers, and thus, firms could benefit more from spending on CSR activities if they understood the impact CSR can have on consumer behavior (Poolthong and Mandhachitara, 2009). A number of authors argue that some unique characteristics in financial services industry such as inseparability between service provider and customers or intangibility of offerings can affect how a consumer evaluates a firm's quality of products/service and the pattern of the relationship between them (Lewis and Soureli, 2006; Bejou et al., 1998). Other researchers also have found the interdependence of customer expectations 
toward CSR and perceived service quality (PSQ) in several studies (Garcia de los Salmones et al., 2005; Brown and Dacin, 1997). According to these findings, CSR can be seen as a powerful tool in building customer perceived quality and brand effect, sometimes referred to as attitudinal loyalty (Poolthong and Mandhachitara, 2009). Additionally, in a high-involvement industry such as financial services customers perceive quality to be a function of trust (Lewis and Soureli, 2006). Considering the other side of the organizations, managers are more willing to consume from a company after exposure some information about its CSR program (Murray and Vogel, 1997). This paper aims to examine the influence of a firm's corporate social responsibility activities on brand equity and perceived service quality, and the impact of perceived quality on brand equity regarding advertising effectiveness as the mediating variable.

\section{Literature Review}

\subsection{Corporate Social Responsibility (CSR)}

Corporate social responsibility (CSR) has been a subject of intense debate among practitioners and scholars for decades (Pearce and Doh, 2005; Galbreath, 2009). However, CSR is obviously viewed both as an organizational function as well as a means to establishing stakeholder relations and reputations (Cornelissen, 2008; Pollach, et.al, 2012). Scholars have presented different definitions for corporate social responsibility. Traditional definition of CSR describes this concept as "The managerial obligation to take action to protect and improve both the welfare of society as a whole and the interest of organization" (Davis and Blomstrom, 1975, p. 6). Brown and Dacin (1997, p. 68) also defined CSR as "the company's status and activities with respect to its perceived societal obligation". Another definition is proposed by Carroll (1991) as "the social responsibility of business (which) encompasses the economic, legal, ethical, and discretionary expectations that society has of organizations". The latter definition of CSR is one of the most widely accepted and used (Poolthong and Mandhachitara, 2009). In addition, the following definition presented by Epstein (1987) reflects growing concerns of management with stakeholders and ethics: Corporate social responsibility relates primarily to achieve outcomes from organizational decisions concerning specific issues or problems which (by some normative standard) have beneficial rather than adverse effects upon pertinent corporate stakeholders. The normative correctness of the products of corporate action are the main focus of CSR (Kim, et.al, 2010). Given the fact that CSR is based on the relationship between the business and society, thus called social contract, it is necessary and natural for this social contract to change in order to reflect society's expectation of business, particularly in the social and ethical realms (Kim, et.al, 2010).

\subsection{CSR and Perceived Service Quality (PSQ)}

Service quality is considered a subjectively oriented construct. Services are relatively intangible, rely on the provider's individual performance and are typically consumed at the same time as their delivery (Forsyth, 2012). Services are intangible, perishable, heterogeneous and inseparable in terms of production and consumption, thus, the criteria used by customers to assess service quality are complex and difficult to determine precisely (Athanassopoulos et al., 2001). Customers do not evaluate service quality only on its outcome (Kotler, 2008), but they base their perception on one or more cues (Poolthong and Mandhachitara, 2009). Gournaris et al. (2003) mentioned that PSQ construct consists of six dimensions: staff competence, service reliability, physical evidence, convenience, product innovation, and value for money. Besides these elements researchers have found a relationship between CSR initiatives and PSQ. Poolthong and Mandhachitara (2009) believe that CSR is a powerful tool in building customer perceived quality. They claim that the level of engagement in certain CSR activities, where consumers expect their service providers to engage, are proposed to influence PSQ. Rummell (1999) studied Body Shop to examine the linkage between the firm's CSR activities and customer's perception of its service quality and found the usage of natural ingredients and environmentally friendly practices is associated with consumer perception of a firm's products and services positively. Garcia de los Salmones et al. (2005) claim that consumers' perception of CSR activities has direct consequences in their assessment of PSQ. Sen and Bhattacharya (2001) also found that consumers are sensitive to the implications of CSR activities. Therefore, the relationship between CSR and PSQ is predicted:

H1: CSR activities have a positive influence on customer's perception of service quality.

\subsection{PSQ, advertising effectiveness and brand equity}

Advertising plays an important role in today's competitive world by which organizations communicate with their 
customers, both current and potential. Companies allocate a considerable part of their sources to advertising (activities). To help evaluate whether or not advertising dollars are earning the best return on investment, it is important to know how effectively advertisement capture and maintain audience attention and engage viewers (De Ros, 2008). Consumers' perception of service quality can play a significant role in their attitudes towards a company's advertising. It can be claimed that effectiveness of advertising is affected by perceived quality, as when customers experience higher levels of quality they would have more positive attitude when facing new advertisement. On the other hand, advertising in turn can improve brand equity through its ability to differentiate a firm's products from those of competitors (Chu and Keh, 2006). Advertising plays a key role in firm's ability to achieve brand equity via relationships with potential and current customers. Marketing practitioners in an attempt to encourage their consumers to choose their brand name have considerable investments in advertising. Although all of marketing activities are crucial for goal achieving, but it is believed that advertising plays a more dramatic role in developing and maintaining brand equity (Aaker, 1991). According to what is mentioned the second and third hypothesis of the study stated:

H2: Perceived service quality affects advertising effectiveness in a positive way.

H3: Advertising effectiveness has a positive impact on brand equity.

\subsection{CSR and Brand equity}

A firm's survival and wealth is determined by its ability to create a superior value to the market (Delgado-Ballester and Munuera-Aleman, 2005). Poolthong and Mandhachitara (2009) believe that CSR is a powerful tool in building customer perceived quality and brand effect, sometimes referred to as attitudinal loyalty. Positive effect of CSR on consumers' attitudes towards the firm and its products has been confirmed in several marketing studies (Poolthong and Mandhachitara, 2009; Bhattacharya and Sen, 2003; Lichtenstein et al., 2004; Luo and Bhattacharya, 2006). Employee commitment, brand image, customer loyalty and market share are some of reported positive consequences of the relationship between CSR and brand effect (Berens et al., 2007; Ginsberg and Bloom, 2004). Thus, the predicted relationship between CSR activities and brand equity is proposed as:

H4: CSR activities influence brand equity positively.

\section{Conceptual Framework of Study}

In this research, as noted, we try to investigate the relationships between CSR activities of a firm and its brand equity and the influence of these activities on perceived service quality and the influence of perceived service quality on brand equity considering advertising effectiveness as the meditative variable. In accordance with literature review and based on developed hypothesis the conceptual framework of the study is hypothesized. Figure 1 illustrates the conceptual model of the research.

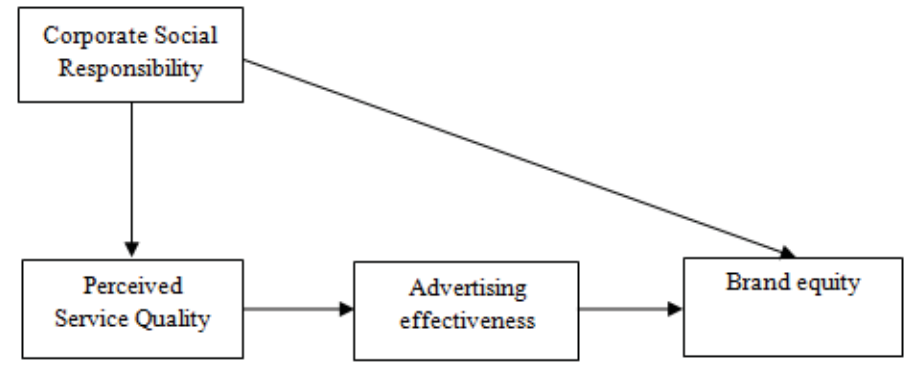

Figure 1. Conceptual framework of study

\section{Research Methodology}

As noted above the aim of this study is to investigate the relations between CSR activities of an organization and its brand equity, regarding the effects of CSR activities on perceived service quality, the effect of perceived service quality on advertising effectiveness and finally the impact that advertising effectiveness can have on brand equity. In order to 
collect the required data for the study, a self-administered survey was used. The questionnaires contain 31 items assigned to 4 variables, CSR activities, perceived service quality, advertising effectiveness and brand equity. In this study, in order to assess the concepts we have used Likert's five-point scale. Measures assessing CSR and perceived service quality by the customers were adopted from Poolthong and Mandhachitara (2009), assessing respondents' perception of the status of organization's CSR activities and its service quality. Items measuring advertising effectiveness were modified from De Ros, (2008). Finally to capture customer's perception of brand equity, items were adapted from Athanassopoulos et al., (2001). The reliability of the questionnaire was calculated by means of Cronbach alpha coefficient and estimated to be 0.921 . Table 1 shows estimated amounts for different items. The research context of this paper is the household appliance industry in Iran. Random sampling method was used to have a sample of 384 respondents. A total of 312 questionnaires were returned, demonstrating a response rate of 81.25 percent.

The validity of the constructs was determined through Confirmatory Factor Analyses. CFA on CSR with 15 items (question 1 to 15), PSQ with 5 items (question 16 to 20), advertising effectiveness with 4 items (question 21 to 24), brand equity with 7 items (question 25 to 31 ) produced the results, representing suitability of the measures to be used for further analysis (Table 2).

Table 1.Research Measures and constructs reliability

\begin{tabular}{ll} 
Construct & Cronbach's Alpha \\
\hline CSR & 0.901 \\
Perceived service quality & 0.884 \\
Advertising effectiveness & 0.800 \\
Brand equity & 0.933 \\
Total & 0.921 \\
\hline
\end{tabular}

Table 2. Results of the Confirmatory Factor Analysis

\begin{tabular}{ll}
\hline chi-square & 204.79 \\
Df & 101 \\
p-value & 0.12 \\
RMSEA & 0.004 \\
\hline
\end{tabular}

\section{Results}

Four predicted relations were examined through Structural Equation Analyses (SEM) using LISREL software. The structural equation modeling technique enables the simultaneous estimation of multiple regression equations in a single framework. Notably, all direct and indirect relations in the model are estimated simultaneously, and thus the method allows all the interrelationships among the variables to be assessed in the same decision context. The sample size in this study was 312, so SEM analysis could be applied, based on appropriate sample size for using Structure Equation Model (SEM) analysis which is 100 to 200 respondents (Bollen, 1989). Covariance matrices were analyzed in all cases using LISREL software. According to the results chi-square is 204.79. Degree of freedom is 101 thus $\chi^{2} \mid \mathrm{df}=2.027$.

Table 3. Fit indices for the path model

\begin{tabular}{ll}
\hline Goodness of Fit Index (GFI) & 0.95 \\
Root Mean Square Error of Approximation (RSMEA) & 0.004 \\
Comparative Fit Index (CFI) & 0.91 \\
Standardized Root Mean Square Residual (SRMR) & 0.003 \\
NFI & 0.98 \\
\hline
\end{tabular}

In line with figure 2 and 3 the results show that the predicted relations of the conceptual model are confirmed. Figure 2 shows the principal model of research and figure 3 illustrates the results of the hypothesis testing. Circumstantial evidence $t$ is used to find out if proposed relationships are significant or not which will be significant when it is higher than 2 ( $t \geq 2)$ in $t$-test and higher than $1.96(z \geq 1.96)$ in z-test. As it is shown in table 4, all of research hypotheses are confirmed statistically. These results indicate that CSR activities of a firm have a positive influence on customer's 
perception of service quality (hypothesis 1 ) and Perceived service quality affects advertising effectiveness in a positive way (hypothesis 2). These results also confirm the positive effect of advertising effectiveness and CSR activities on brand equity (hypothesis 3 and 4).

Table 4. Analysis of the results

\begin{tabular}{llllll}
\hline Path & & Hypotheses & Coefficient & $\begin{array}{l}\text { T- } \\
\text { value }\end{array}$ & $p$ \\
\hline CSR & $\rightarrow$ Perceived Service Quality & H1 & 0.62 & 20.85 & $<0.05$ \\
Perceived Service Quality & $\rightarrow$ Advertising effectiveness & H2 & 0.43 & 19.56 & $<0.05$ \\
Advertising effectiveness & $\rightarrow$ Brand equity & H3 & 0.62 & 7.72 & $<0.05$ \\
CSR & $\rightarrow$ Brand equity & H4 & 0.56 & 10.21 & $<0.05$ \\
\hline
\end{tabular}

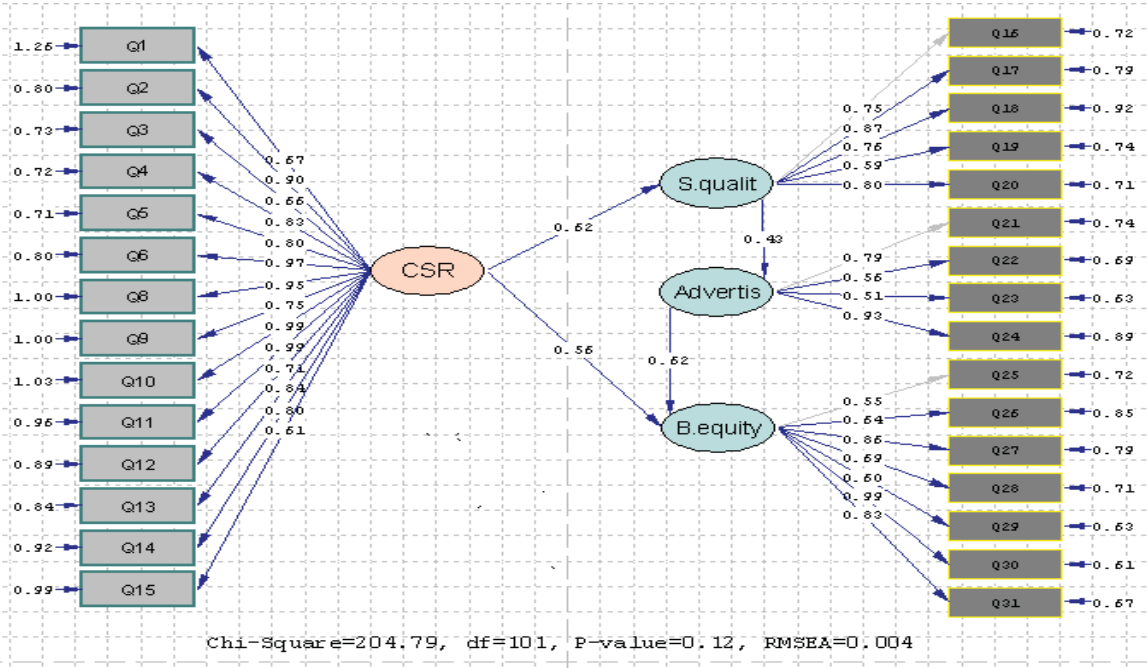

Figure 2 . Principal Model of Research

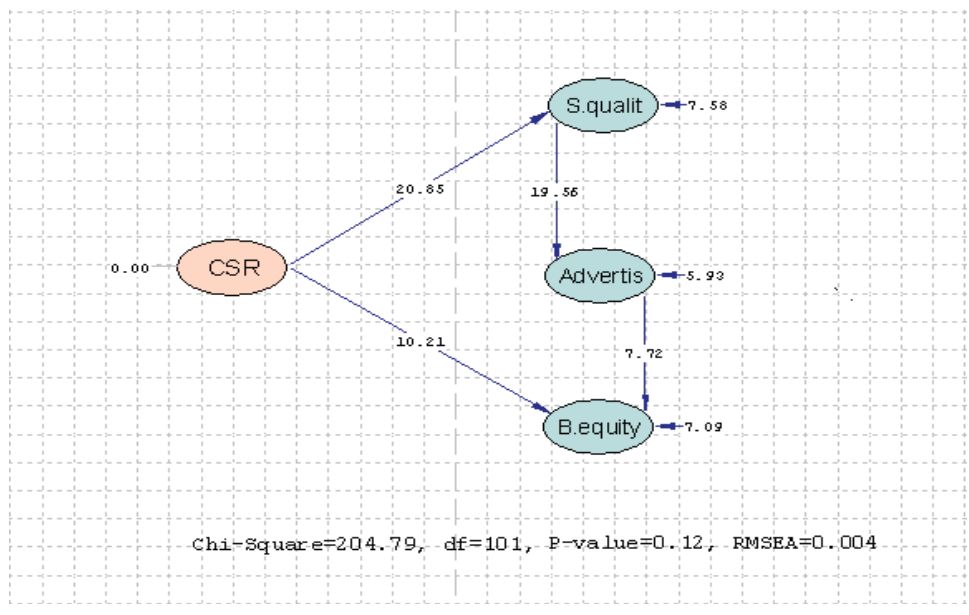

Figure 3. Model of Adjusted Index of T 


\section{Conclusion}

Building a strong brand in a marketplace is the goal of all the organizations as it can provide a host of benefits for a firm, including less vulnerability to competitive marketing actions, larger margins, greater intermediary co-operation and support, and brand extension opportunities (Delgado-Ballester and Munuera-Alemán, 2005). On the other hand, companies have to involve in different types of social responsibility activities, such as acts of responsibility towards the environment, treating employees fairly or contributions to art and cultural programs in the community (Barone et al., 2000). The purpose of this study was to investigate how social responsibility activities can affect brand equity in a positive way despite the possible negative attitudes towards this relation. The results confirmed that the more companies involve in social activities the more they can influence their perceived brand equity by the consumers. These kinds of activities also can improve their perceived quality which in turn contributes the enhancement of brand equity. These findings provide companies a foresight to understand the importance of social concerns as a leverage to enhance their reputation. Companies with higher levels of social activities are better able to enhance their status in the competitive market by means of influencing consumers' attitudes towards their brand.

\section{References}

Aaker, DA. ( 1991). Managing Brand Equity. New York: The Free Press.

Argenti, P.A., Howell, R.A. and Beck, K.A. (2005), "The strategic communication imperative", MIT Sloan Management Review, 30-9.

Athanassopoulos, A., Gounaris, S. and Stathakopoulos, V. (2001), "Behavioral responses to customer satisfaction: an empirical study", European Journal of Marketing, 35 (5/6), 687-707.

Barone, M.J., Miyazaki, A.D. and Taylor, K.A. (2000), "The influence of cause-related marketing on consumer choice: does one good turn deserve another?", Journal of the Academy of Marketing Science,. 28 (2), 248-62.

Bejou, D., Ennew, C.T. and Palmer, A. (1998), "Trust, ethics and relationship satisfaction", International Journal of Bank Marketing,. 16 (4), $170-5$.

Berens, G., van Riel, C.B.M. and van Rekom, J. (2007), "The CSR-quality trade-off: when can corporate social responsibility and corporate ability compensate each other?", Journal of Business Ethics, 74 (3), $233-52$.

Bhattacharya, C.B. and Sen, S. (2003), "Consumer-company identification: a framework for understanding consumers' relationships with companies", Journal of Marketing, 67. 68-76.

Bollen, Kenneth A.(1989). Social sciences; Latent variables; Statistical methods. Newyork;willey.p,514 .

Brown, T.J. and Dacin, P.A. (1997), "The company and the product: corporate associations and consumer product responses", Journal of Marketing, 61. 68-84.

Carroll, A.B. (1991), "The pyramid of corporate social responsibility: toward the moral management of organizational stakeholders", Business Horizons, 39-48.

Chaudhuri, A. and Holbrook, M.B. (2001), "The chain of effects form brand trust and brand effect to brand performance: the role of brand loyalty", Journal of Marketing, 65 (2). 81-93.

Chiou, J.S. and Droge, C. (2006), "Service quality, trust, specific asset investment, and expertise: direct and indirect effects in a satisfaction-loyalty framework", Journal of the Academy of Marketing Science, 34 (4). 613-27.

Cornelissen, J.P. (2008), Corporate Communication, Sage, London.

Davis, K. and Blomstrom, R.L. (1975), Business and Society: Environment and Responsibility, McGraw-Hill, New York, NY.

De Ros, k. M. (2008).A Content Analysis of Television Ads: Does Current Practice Maximize Cognitive Processing?.Indiana University.

Delgado-Ballester, E. and Munuera-Aleman, J.L. (2001), "Brand trust in the context of consumer loyalty", European Journal of Marketing. 35 (11/12). 1238-58.

Epstein, E. (1987), "The corporate social policy process: beyond business ethics, corporate social responsibility, and corporate social responsiveness", California Management Review, 29. 99-114.

Forsyth, P. J. (2012). "Profiling customer perceived service quality expectations in made-to-order housing construction in Australia", Engineering, Construction and Architectural Management, 19 (6). 587609

Galbreath, J. (2009). " Building corporate social responsibility into strategy", European Business Review, 21 (2). 109-127

Garcia de los Salmones, M.d.M., Crespo, A.H. and del Bosque, I.R. (2005), "Influence of corporate social responsibility on loyalty and valuation of services", Journal of Business Ethics, 61 (4), 369-85.

Lewis, B.R. and Soureli, M. (2006), "The antecedents of consumer loyalty in retail banking", Journal of Consumer Behavior, 5, 15-31.

Ginsberg, J.M. and Bloom, P.N. (2004), "Choosing the right green marketing strategy", MIT Sloan Management Review, 79-84.

Gournaris, S.P., Stathakopoulos, V. and Athanassopoulos, A.D. (2003), "Antecedents to perceived service quality: an exploratory study in the banking industry", International Journal of Bank Marketing, 21 (4), 168-90.

Kim, J, Kwak, G and Koo, Y. (2010). "A note on corporate social responsibility (CSR) in city branding and design", The Asian Journal on Quality,. 11 (3), 251-265.

Kotler, P. (2008), Marketing Management, 13th ed., Prentice Hall, Upper Saddle River, NJ. 
Lewis, B.R. and Soureli, M. (2006), "The antecedents of consumer loyalty in retail banking”, Journal of Consumer Behavior, 5, 15-31.

Lichtenstein, D.R., Drumwright, M.E. and Braig, B.M. (2004), "The effects of corporate social responsibility on customer donations to corporate-supported nonprofits", Journal of Marketing, 68, 16-32.

Luo, X. and Bhattacharya, C.B. (2006), "Corporate social responsibility, customer satisfaction, and market share value", Journal of Marketing, 70, 1-18.

McAllister, D.J. (1995), "Affect and cognition based trust as foundations for interpersonal cooperation in organizations", Academy of Management Journal, 38, 24-59.

Murray, K.B. and Vogel, C.M. (1997), "Using a hierarchy of effects approach to gauge the effectiveness of CSR to generate goodwill towards the firm: financial versus nonfinancial impacts", Journal of Personality and Social Psychology, 48 (3), 575-84.

Nijssen, E., Singh, J., Sirdeshmukh, D. and Holzmueller, H. (2003), "Investigating industry context effects in consumer-firm relationships: preliminary results from a dispositional approach", Journal of the Academy of Marketing Science, 31(1), 46-60.

Pearce, J.A. II and Doh, J.P. (2005), "The high impact of collaborative social initiatives", MIT Sloan Management Review, 46 (3), $30-9$.

Pirch, J., Gupta, S. and Grau, S.L. (2007), "A framework for understanding corporate social responsibility programs as a continuum: an exploratory study", Journal of Business Ethics, 70 (2), 12540.

Pollach, I, Johansen, T. S, Nielsen, A. E and Thomsen, C. (2012). " The integration of CSR into corporate communication in large European companies", Journal of Communication Management, 16 (2), 204-216

Poolthong, Y and Mandhachitara, R. (2009). "Customer expectations of CSR, perceived service quality and brand effect in Thai retail banking", International Journal of Bank Marketing, 27 (6), 408-427.

Rotter, J.B. (1967), "A new scale for the measurement of interpersonal trust”, Journal of Personality, 35 (4), $651-65$.

Rummell, T. (1999), "What's new at the body shop?", Global Cosmetic Industry, 165 (5), 16-18.

Sen, S. and Bhattacharya, C.B. (2001), "Does doing good always lead to doing better? Consumer

reactions to corporate social responsibility", Journal of Marketing Research, 38 (2), 225-43.

Sirdeshmukh, D., Singh, J. and Sabol, B. (2002), "Consumer trust, value, and loyalty in relational exchanges", Journal of Marketing, 66, 15-37. 
